Anandh K S., Prasanna K., Gunasekaran K. and Aravinth K S(2018). "An exploratory study on lean teaching adoption rate among academia and industry in Indian scenario." In: Proc. $26^{\text {th }}$ Annual Conference of the International. Group for Lean Construction (IGLC), González, V.A. (ed.), Chennai, India, pp. 1395-1404. DOI: doi.org/10.24928/2018/0498. Available at: www.iglc.net

\title{
AN EXPLORATORY STUDY ON LEAN TEACHING ADOPTION RATE AMONG ACADEMIA AND INDUSTRY IN INDIAN SCENARIO
}

\author{
Anandh K S ${ }^{1}$, Prasanna $K^{2}$, Gunasekaran $K^{3}$ and Aravinth K $S^{4}$
}

\begin{abstract}
Construction sector is undergoing a paradigm shift with the adoption and implementation of new technologies concepts. One among these concepts is Lean Construction, which improves productivity, allocation of construction drawings, detailing, time management, costs control, people management and safety at construction sites. For the effective adoption of Lean construction, professionals require basic understanding of the concepts. To facilitate this, construction and engineering management programs need to introduce Lean concepts in their curriculum, educating students about relevant thoughts and philosophy. The Lean approaches would take them a notch higher concerning productive future career prospects in the construction industry.

For this study, data has been collected from various colleges and universities of South India. Research data was collected through semi-structured questionnaires in addition to semi-structured interview. Results of this study provided extraordinary views which is beneficial for curriculum designers and even the top management of construction. The main aim of the study is to determine the current scenarios of Lean teaching and practicing in the industry and demand rate/ awareness about the Lean Teaching. This paper helps in understanding the current status of Lean adoption in academia and also in construction industry.
\end{abstract}

\section{KEYWORDS}

Lean Theories, Teaching, Construction Management, Engineering education, Game learning

1 Assistant Professor, Department of Civil Engineering, SRM Institute of Science and Technology, Kattankulathur, India. +91979074077, anandh.k@ktr.srmuniv.ac.in

2 Assistant Professor, Department of Civil Engineering, SRM Institute of Science and Technology, Kattankulathur, India.+919444455715, prasanna.k@ktr.srmuniv.ac.in

3 Professor, Department of Civil Engineering, SRM Institute of Science and Technology, Kattankulathur India.+919443353507, gunasekaran.k@ktr.srmuniv.ac.in

4 Deputy Project Manager, Land Transport Authority, Singapore. +6597964037, aravinthks@live.com 


\section{INTRODUCTION}

Construction industry in India is one vital source of socio-economic growth. The workforce involves not only the professionals but also skilled, unskilled workers from various places, irrespective of gender. Construction industry offers more employment and contributes towards the national GDP. Current Indian economy is of 2-5 trillion USD which is about $7.4 \%(2018-19)$. Growth expected is at $8-15 \%$ which proposes extra expenditure on infrastructure projects of 5.97 lakh area with outlast of 2.04 lakh area for smart cities, allocation of 1.48 lakh crores for Indian railway and targeting almost $9000 \mathrm{kms}$ of highway construction within the end of 2018. The government is providing more support for infrastructure, and construction sector hence both the urban and rural areas are to be taken into account.

\section{BACKGROUND}

\section{TEACHING METHODOLOGY ADOPTED IN INDIA}

Teaching starts at the age of 3 years at kindergarten schools where trained teachers conduct visual aids, models, and interactive sessions. Various boards offer different curriculum up to 12th standard, namely State Board, Central Board of Secondary Education, Indian Certificate of Secondary School, Anglo-Indian in different states and union territories. For graduate studies (Under Graduate /Post Graduate) there are numerous institutions and universities, colleges under government scheme and aided colleges with financial support and self-financing colleges with autonomous status and deemed to be universities in private sectors. Each institution or college or university adopts a different curriculum to ensure that the education imported is in line with market requirements.

\section{ENGINEERING EDUCATION}

Before independence of India, there were only Government Engineering Colleges and Government Aided Engineering colleges affiliated to the State Government Universities to award the degree under standard norms. As per the current status, there are 3345 engineering colleges across India which can accommodate 1473871 students with 63 Under Graduate disciplines with the major category of Civil, Mechanical, Electrical, Electronics, Computer science, Information Technology, Bio-Technology. The growing need in the industry saw the evolution of the engineering and information technology and many engineering colleges had been established. To develop the job-oriented programmes, both the industry and academia should be considered (Ross B. Corotis, and Robert H. Scanlan,1989). More than traditional learning methods, teaching through projects work, tutorials would meet the educational objectives. (Betts and Liow 1993). In Civil Engineering Education, the teaching methods are seeing a marked change moving from chalk and talk to systems-based learning, online courses, self-paced courses, which are more significant innovations (Duncan and Mckeachie 2005; Vesilind 1991). Educational objectives and evaluating of coursed design on the par with the curriculum has been tailored to make the student industry ready in the global platform has been set 
(Martin et al. 2014)as there will always be a relationship between work exposure at the line graduation and employability in all sectors (Murphy et al. 2009)

\section{LEAN TEACHING}

"Lean Construction (LC)" is the application of the Lean concept that was primarily initiated from Toyota Production System (TPS) to construction sector, focused on creating value on client's requirement. Human behavior with regards to the transition from a traditional way philosophy of manufacturing to the practicing of the Leanconcepts had taken into consideration. Resistance to change in adopting the Lean philosophy inhibits an organization. Both management and employees are the motivational catalyst for Lean organizational change (Keyser et al. 2016). Lean teaching in the classrooms is to be considered only if there is a proper understanding, awareness, and knowledge towards Lean in construction. (Koskela et al. 2002). There are various other factors that influence productivity concerning it, adopting new technology and new concepts will increase productivity of engineers (Anandh and Gunasekaran 2016; Kiruthiga et al. 2015)

As specified there are different service sectors like Health care, IT etc. from manufacturing industries to construction industry that adopted the strategies of Lean theories. Lean thinking should be incorporated to construction management platform (Jacobs et al. 2012) The paradigm shift is always trying to dislodge an organization system, practices and regular work. Many universities in western countries have understood the demand in the real construction field and have been giving courses on Lean concepts for both undergraduates and postgraduates students (Tsao et al. 2013). Always, a new way of thinking about Lean is a good appeal to demonstrate Lean teaching in the construction industry which includes, discussions, teamwork, assignments, practices, expertise talk, site visits, and textbooks (Tommelein 2004). Even the countries where teaching Lean concepts towards construction practice are ongoing are facing un clarity of knowledge regarding demand rate and principles behind it. (LCI).

Implementing tools and techniques will reduce or avoid the effect on the productivity of civil engineers, there will always be a healthy relationship between the working conditions and professional support concerning job satisfaction which implies the adoption of new techniques into practice too. (Anandh and Gunasekaran 2017; Anandh and Manna Simon 2017). A set of Lean skills and qualifications that are relevant for construction, is required. There is a lack of Lean skills and known mainly for entry-level professionals as the company is expecting professionals with knowledge of both soft and hard techniques of Lean. (Alves et al. 2016). There are differences in teaching approaches, experiences and lessons learned from course offered. In addition, the method of teaching Lean requires, combinations of reading, lectures, discussions, simulations, exercise and field trip and guest speakers. Online methods will be more useful in supporting classroom teaching. There are challenges by using Lean concepts in construction in real time (1) there are many meanings when applied to construction industries (2). Having academics continually working with industry practitioners to keep working on new concepts aided with tools along with this, thoughtful insights in gaining learning process LC may have gazed as fantasy in the real construction sector (Murphy et al. 2009; Tsao et al. 2013). 


\section{AIM AND OBJECTIVE}

The need of the hour: Extensive research to explore the importance of Lean teaching and its subsequent implementation in academia and industry.

The objectives of the study involve

- To analysis/capture the awareness \&demand of Lean construction in academia and industry respondents.

- To seek insights concerning Lean construction teaching from the prerogative of the teaching faculty and civil engineers in the south Indian scenario.

\section{RESEARCH DESIGN}

In this project, both qualitative and quantitative approaches were used to research design, email-based survey, and direct interview with experts from both academic and construction industry. The study was appropriately focusing on the teaching fraternity pertain to civil engineering and construction engineering management, civil engineers in real time projects and Lean experts. In academia, the target audiences were the Heads of Department, Professors, Assistant Professors, faculty who completed the Under graduation in civil engineering along with post-graduation in construction engineering and management, any person specialized in teaching Construction management and research scholars. Various universities /engineering colleges in the southern part of India and very few from universities abroad were invited to participate in a survey including construction industry project managers, civil engineers, and Lean practitioners. A similar exercise was carried for academia, in the industry too; the southern part of India and few from abroad being invited for the survey. The exposure rate of Lean Teaching/Practicing is higher comparatively in abroad (Singapore, USA and Australia) than in India. In total 180 individuals were asked to participate in the study. Yield response rate of $62 \%$, i.e. 110 involved themselves in completing the survey with great and useful insights. The basic information obtained from the respondents is given in Table 1.

\section{DATA ANALYSIS}

All the data assimilated was analyzed using the statistical package for the social sciences (SPSSV20.0) Software for chi-square test and discriminant function analysis and Microsoft Excel for pictorial representations. This was successful in providing an overall view about Lean teaching and practicing in south India.

\section{RESULTS AND DISCUSSION}

The outcomes from the detailed analysis were recorded, and detailed representation is depicted in Fig 1. It is evident that teaching Lean concepts is nearly 50\% and $30.8 \%$ not practiced and $19.2 \%$ may be practiced shortly. The teaching, however, is not directly through courses but in the form of projects and research work only. Relevance rate also gazes into a new way for Lean teaching in Indian construction industry. It implies that $85 \%$ are aware of it. But it does not appear in the curriculum directly. It was noted that conferences/ workshops, magazines, Journals, blogs, online portals are the sources of Lean exposures. 
Table 1: Demographic Profile

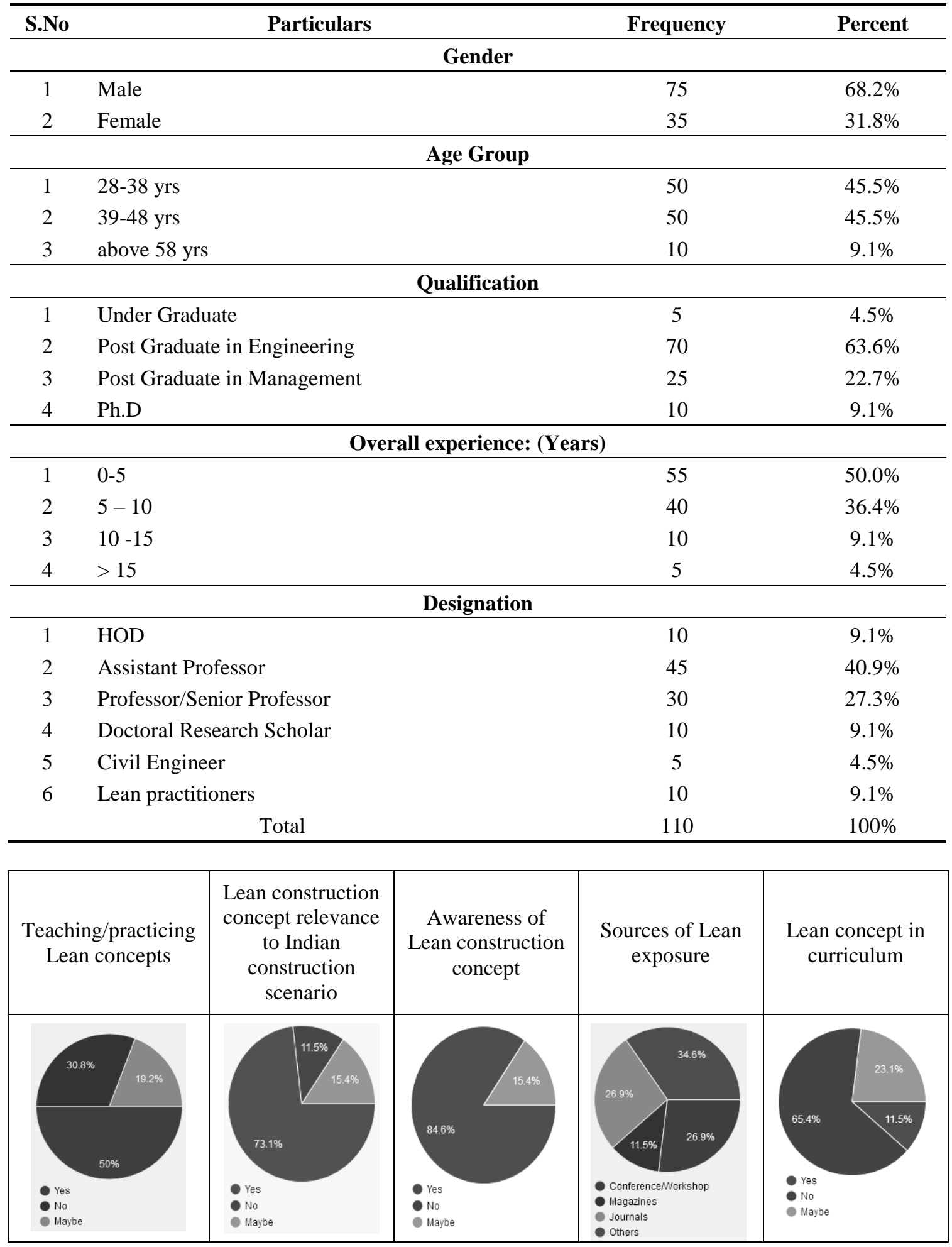

Figure 1: various aspects from the outcomes of respondents 


\section{DISCRIMINANT FUNCTION ANALYSIS (DFA)}

Factors discriminant people who are aware and unaware of the Lean Construction Concept.

The discriminant function analysis is a very useful tool for:

(1) Finding the permissible variable to discriminate between different sets,

(2) Segregate the cases into different accurate sets.

In this study, the DFA was used to determine which variables discriminate between respondents based on their awareness about the Lean construction concept and the demand for Lean construction concept.

While performing a multiple set discriminant analysis, it is not required to specify how to associate sets to structure different discriminant functions. Some best blend s of variables is to be found, for that the 1) function gives the comprehensive discrimination betweensets.2) Offers second most, and so on. Moreover, the functions will be independent or equilateral, that is, theinput to the discrimination between sets do not overlay. Figuring out, perform a canonical correlation analysis is performed to determine the continuous functions and canonical roots (the term root refers to the Eigen values that are associated with the respective canonical function).

The result has given $b$ (and standardized beta) coefficients for each variable in each discriminant (now also called canonical) function, and these can be explained as more critical, the normalized coefficient, more handouts of the respective variable to the discrimination between groups.

DFA estimation was assumed that the data (for the variables) represented a sample from a multivariate normal distribution. It was also believed that the variance/covariance matrices of variables were similar across the compared set. One more assumption of DFA was that the variables that are used to discriminate between other sets were not entirely inessential. The linear model has been performed for this DFA

$$
\begin{aligned}
& Z=b_{1} X_{1}+b_{2} X_{2}+\ldots \ldots \ldots . .+b_{i} X_{i} \quad(i=1,2,3 \ldots \ldots 7) \text { (Awareness) } \\
& Z=b_{1} X_{1}+b_{2} X_{2}+\ldots \ldots \ldots \ldots+b_{i} X_{i} \quad(i=1,2,3 \ldots \ldots 8) \text { (Demand) }
\end{aligned}
$$

Where, $\mathrm{Z}=$ Total discriminant score $\mathrm{X}_{\mathrm{I}}=$ Demographic Variables

Table 2: Wilks' Lambda (WL) values awareness and demand

\begin{tabular}{ccccc}
\hline Functional Test & WL & Chi-square & DF & Sig. \\
\hline Awareness & $0.498^{* *}$ & 73.954 & 4 & .000 \\
Demand & $0.428^{* *}$ & 89.168 & 6 & .000 \\
\hline
\end{tabular}

The results of the DFA are shown in Table 2,3 and 4. The Table no. 2 shows the test of discriminant function. The Wilks' Lambda value and the corresponding chi-square statistic are significant $(\mathrm{p}<0.01)$ at 99 per cent level. 
Table 3: Results of Discriminant Function

\begin{tabular}{lcr}
\hline \multirow{2}{*}{ Demographic Variables } & \multicolumn{2}{c}{ Discriminant function co-efficient } \\
\cline { 2 - 3 } & Awareness & Demand \\
\hline Teaching/practicing Lean concept & $0.481^{*}$ & $0.566 *$ \\
Gender & $0.281^{*}$ & $-0.085^{*}$ \\
Age (in years) & $-0.230^{*}$ & $0.000 *$ \\
Experience in present organisation & $0.188^{\mathrm{NS}}$ & $0.141^{\mathrm{NS}}$ \\
Overall experience & $0.171^{*}$ & $0.146^{*}$ \\
Designation & $-0.147^{\mathrm{NS}}$ & $-0.273^{\mathrm{N}}$ \\
Qualification & $-0.036^{\mathrm{NS}}$ & $-0.005^{\mathrm{NS}}$ \\
Awareness of Lean construction concept & & $0.374 *$ \\
\hline
\end{tabular}

Table 4. Classification of results with respect to awareness and demand

\begin{tabular}{|c|c|c|c|c|c|c|c|c|c|c|}
\hline \multicolumn{11}{|c|}{ Classification Results with respect to awareness and demand } \\
\hline \multicolumn{6}{|c|}{ Predicted Group Membership } & \multicolumn{5}{|c|}{ Predicted Group Membership } \\
\hline Lean con & istructio & n concept & Aware & Unaware & Total & $\begin{array}{l}\text { Perceptic } \\
\text { Demand }\end{array}$ & on on & Demand & $\begin{array}{l}\text { No- } \\
\text { demand }\end{array}$ & Total \\
\hline \multirow[t]{4}{*}{ Original } & Count & Aware & 10 & 5 & 15 & Original & Count & Demand & 40 & 55 \\
\hline & & Un aware & 0 & 95 & 95 & & & No-Demand & 10 & 55 \\
\hline & $\%$ & Aware & 66.7 & 33.3 & 100.0 & & $\%$ & Demand & 72.727 .3 & 100.0 \\
\hline & & Un aware & 0.0 & 100.0 & 100.0 & & & No-Demand & 18.281 .8 & 100.0 \\
\hline \multicolumn{6}{|c|}{ a. $95.5 \%$ of original set correctly classified } & \multicolumn{5}{|c|}{ a. $77.3 \%$ of original sets correctly classified } \\
\hline
\end{tabular}

The results of the discriminant function analysis and the discriminant score for each respondent was seen to be post-stratified into either aware or Un aware and demand rate of the Lean construction concept gives the how to know the effectiveness of discriminant function analysis. The classification results are given in Table 4. It could be inferred that $95.5 \%$ concerning awareness and $77.3 \%$ concerning demand rate of original sets were correctly classified by this discriminant function model.

The data on qualification and overall experience with respect to level of curriculum design the teaching / practicing of Lean concept was analyzed by chi-square test is describes Table 5. The outcome of analysis acknowledged that is significant statistically $(\mathrm{p}<0.05)$ association existing between both qualification and overall experience with respect to level of curriculum design the teaching / practicing of Lean concept.

The data on gender and designation wise response to the teaching / practicing of Lean concept was analyzed by chi-square test as seen in Table 6 . The outcome of analysis acknowledged that is significant statistically $(\mathrm{p}<0.05)$ association exist between both gender and designation concerning teaching / practicing Lean concept. 
Table 5: Level of curriculum design gives importance Lean concepts

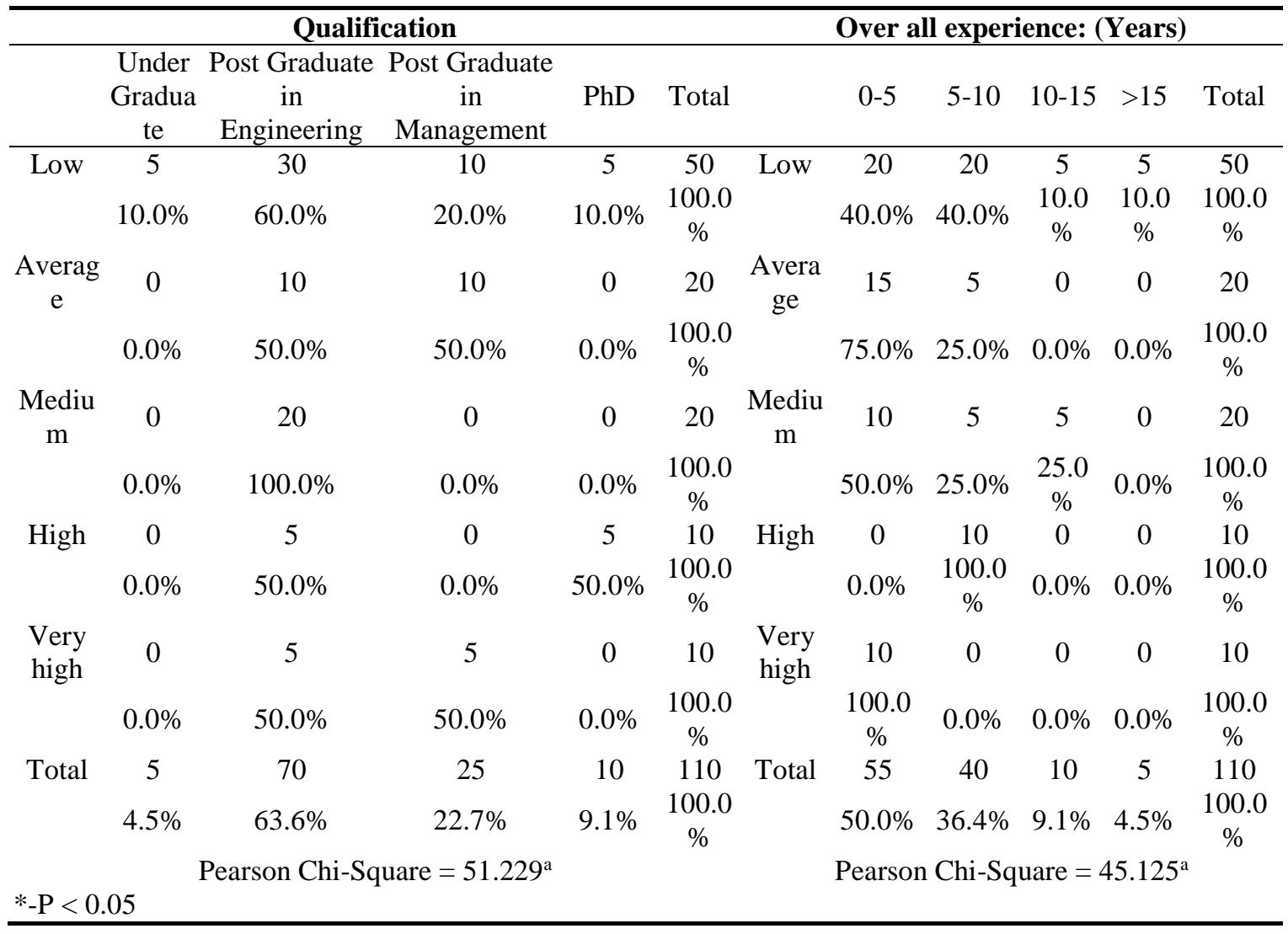

Table 6: Teaching / Practicing Lean concept with respect to Gender and Designation

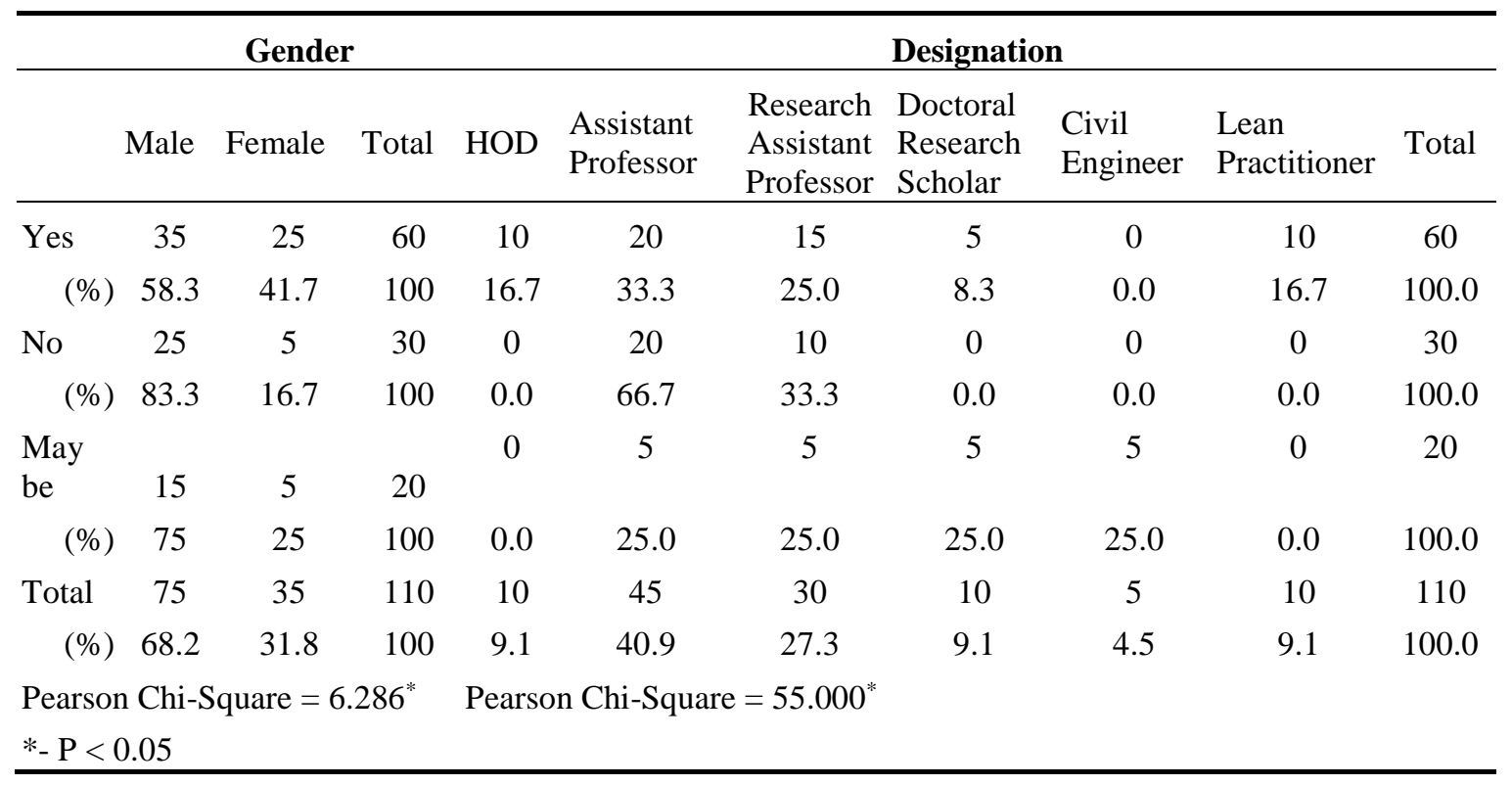




\section{CONCLUSIONS}

Based on the results, it can be seen that Lean construction awareness is high in the industry as Lean is considered as one of the effective Business model compared to the awareness in academia, where the premier institutes have relatively high exposure. Most of the colleges/universities does not offer Lean construction through their curriculum which directly impacts the development of the industry. When compared to senior faculties of the academia, younger professor's shows more interest in learning and teaching new concepts. The amount of research, teaching and practices adopted in the area of Lean construction in India is comparatively low with respect to other countries. It is also realized that Lean Construction is in the infant stage of growth and the availability of Lean experts is limited. It is also observed during the study that certain SME's has practices that aligns with Lean concepts, but the group is not aware of the Lean philosophy, which is a evidence for low awareness. Hence, this study would give wide publicity to the users and make them more comfort exposure.

\section{RECOMMENDATIONS}

In the Table.7 the insights of various respondents are narrated and recommended to both academia and industry for formulating Lean Teaching and practices

Table 7: Recommendations Insights

\begin{tabular}{lll}
\hline \multicolumn{2}{c}{ Academia } & \multicolumn{1}{c}{ Industry } \\
\hline$* \begin{array}{l}\text { Inclusion of Lean teaching in Civil } \\
\text { Engineering curriculum at the UG level }\end{array}$ & $\begin{array}{l}\text { Policies/ standard can be implemented in construction } \\
\text { companies at the contractual period itself }\end{array}$ \\
$* \begin{array}{l}\text { Inclusion of separate courses/ project for } \\
\text { Construction Engineering Management } \\
\text { courses }\end{array}$ & $* \begin{array}{l}\text { Client driven and client awareness drive can be initiated } \\
\text { in company though company magazines, journals }\end{array}$ \\
$* \begin{array}{l}\text { Research works and paper publications } \\
\text { to be increased in Indian context. }\end{array}$ & $* \begin{array}{l}\text { Training for Civil Engineers } \\
\text { Application can be developed for monitoring Lean } \\
\text { praining programmes for Teaching } \\
\begin{array}{l}\text { Faculty - by experts to be organized. } \\
\text { progressing }\end{array} \\
\text { Initiative awareness programmes can be } \\
\text { conducted for students }\end{array}$ & $* \begin{array}{l}\text { Short term executive courses can be conducted by } \\
\text { experts }\end{array}$ \\
$* \begin{array}{lll}\text { Interesting game learning can } \\
\text { introduced. }\end{array}$ & $* \begin{array}{l}\text { Successful Lean stories can be shared to them } \\
\text { International exposures should be showcased to civil } \\
\text { engineers }\end{array}$ \\
\hline
\end{tabular}

\section{REFERENCES}

Alves, T. C. L., Azambuja, M. M., and Arnous, B. (2016). "Teaching Lean Construction : a Survey of Lean Skills and Qualifications Expected By Contractors and Specialty Contractors in 2016." International Group for Lean Construction, 13-21.

Anandh, K. S., and Gunasekaran, K. (2016). "Constructing a Model to Examine the Influence of Quality of Work-Life on Work-Life Balance - Discernment of Civil 
Engineers from Construction Industry in Chennai." Indian Journal of Science and Technology, 9(40).

Anandh, K. S., and Gunasekaran, K. (2017). "An Individualised Investigation on The Impacts of Job Support Factors Affecting The Efficiency of Construction Engineers." Proceedings for the Indian Lean Construction Conference - ILCC 2017 Construction, C32-C40.

Anandh, K. S., and Manna Simon, S.. (2017). "Assessment of Factors Influencing Productivity of Construction Engineers." Proceedings for the Indian Lean Construction Conference - ILCC 2017 Construction, C26-C31.

Betts, M., and Liow, S. R. (1993). "The relationship between teaching methods and educational objectives in building education." Construction Management and Economics, 11(2), 131-141.

Duncan, T. G., and Mckeachie, W. J. (2005). "The Making of the Motivated Strategies for Learning Questionnaire." Educational Pschologist, 40(2), 117-128.

Jacobs, F., Folkestad, J. E., and Glick, S. (2012). "Review of construction Lean research studies in support of Lean transformation to the construction operating platform." Journal of Enterprise Transformation, 2(3), 157-176.

Keyser, R. S., Sawhney, R. S., and Marella, L. (2016). "A management framework for understanding change in a Lean environment." Tékhne, Instituto Politécnico do Cávado e do Ave (IPCA), 14(1), 31-44.

Kiruthiga, K., Anandh, K. S., and Gunasekaran, K. (2015). "Assessment of influencing factors on improving effectiveness and productivity of construction engineers." International Journal of Applied Engineering Research, 10(17), 13849-13854.

Martin, D., Plugge, P. W., Ph, D., Bender, W., and Ph, D. (2014). "Integrated Project Delivery Games for the Classroom."

Murphy, C. F., Allen, D., Allenby, B., Crittenden, J., Davidson, C. I., Hendrickson, C., and Matthews, H. S. (2009). "Sustainability in Engineering Education and Research at U.S. Universities." Environ. Sci. Technol., 43(15), 5558-5564.

Ross B. Corotis and Robert H. Scanlan, (1989). "Future of Civil Engineering Profession and Role of Education" J. Prof. Issues in Engrg., 115(2), 117-124.

Tommelein, I. D. (2004). "Project Organizations as Social Networks." Journal of Construction Engineering and Management, 136(4), 107-118.

Tsao, C. C. Y., Azambuja, M., Hamzeh, F., Menches, C., and Rybkowski, Z. K. (2013). "Teaching Lean Construction - Perspectives on Theory and Practice." Proceedings for the 21th Annual Conference of the International Group for Lean Construction, 977-986.

Vesilind, B. P. A. (1991). "What should weteach civil engineering students?" 117(25967), 287-294. http://www.indiabudget.gov.in/ Retrieved on 14.02.2018 